\title{
EVALUATION OF EFFECTIVENESS OF BISPHENOL A REMOVAL ON DOMESTIC AND FOREIGN ACTIVATED CARBONS
}

\author{
SKUTECZNOŚĆ USUWANIA BISFENOLU A NA KRAJOWYCH \\ I ZAGRANICZNYCH WEGLACH AKTYWNYCH
}

\begin{abstract}
Wide use of bisphenol A (BPA) in production of polycarbonates and plastic food packaging cause increase of concentration of BPA in the environment. Both in surface water, underground water and seawater BPA was frequently detected in different concentrations. Emerging problem is adsorption of BPA on sewage, because it could be considered as an additional source of pollution, if it is used as a fertilizer in agricultural sectors. Absorbed BPA on sewage sludge stays persistent in the environment and generates adverse biological effects in endocrine system. Because of ecological safety, exploration of potential techniques to remove BPA to the level, which does not give adverse effect on natural environment is necessary. In this study the adsorption of BPA from simulated water onto commercial activated carbons was investigated. On the basis of experimental data the kinetics and type of sorption were determined.
\end{abstract}

Keywords: micropollutants, sorption, activated carbons

\section{Introduction}

In recent years, increasing attention is focused on the presence of xenoestrogens in the aquatic environment, that degrade its quality and cause disturbances in endocrine system of living organisms. Among xenoestrogens one of the most prevalent is bisphenol A (BPA), which occurrence in the environment is connected with anthropogenic activity. BPA is mainly used for production of epoxy resin and polycarbonate plastics. Therefore industrial and municipal wastewater and landfill leachates have to be considered as point sources of BPA. In recent works the presence of BPA have been documented in different matrices such as: sewage sludge, effluents from wastewater treatment plant, river water and landfill leachate [1-4]. The results provided by Gibson et al from Mexico City wastewaters showed concentrations of BPA ranged from 0.77 to $2.5 \mu \mathrm{g} / \mathrm{dm}^{3}$ [4]. The study conducted in Toronto reported widely divergent concentration of BPA in wastewater from different industrial sectors. Concentration of BPA ranged $0.08-91.27,0.75-43.45,0.1-0.48 \mu \mathrm{g} / \mathrm{dm}^{3}$ for

\footnotetext{
${ }^{1}$ Institute of Water and Wastewater Engineering, Silesian University of Technology, ul. Konarskiego 18, 44-100 Gliwice, Poland, phone +48 322371698 , fax +48 322371047

*Corresponding author: gabriela.liszczyk@ polsl.pl
} 
wastewater from chemical products industry, commercial laundries, textile and clothing industries, respectively. Yamamoto et al [5] determined concentration of BPA in some samples from hazardous waste landfill leachates with median concentration $269 \mu \mathrm{g} / \mathrm{dm}^{3}$. Latter publications reported concentration of BPA in municipal landfill leachates in the range $26-8400 \mu \mathrm{g} / \mathrm{dm}^{3}[6]$.

The significance of the problem of BPA in the environment is intensified by physicochemical properties of this compound such as low solubility and high hydrophobicity characteristics. These properties suggest that BPA has low biodegradability and accumulates in living organisms.

The influence of BPA presence even at low concentration in the environment can cause feminization of aquatic organisms, decrease in population fertility and survival of progeny. Wide ranging global studies have demonstrated that exposure to BPA, interfere endocrine system in diverse range of concentrations and the effects can be very unpredictable as a consequence of its ability to initiate numerous responses [7-10].

According to U.S. Environmental Protection Agency (EPA) BPA has been identified as an "exogenous" agent, that interfaces with synthesis, secretion, transport, binding action or elimination of natural hormones in the body that are responsible for the maintenance of homeostasis, reproduction or behaviour.

Given the ecological safety it is advisable to develop effective technology of removal of BPA to the level, excluding their negative impact on the environment.

Some investigations have indicated, that pressure membrane techniques (nanofiltration, reverse osmosis) and advanced oxidation processes are efficient to remove bisphenol A [11-16].

Adsorption is one of the simplest and widely used methods that can be applied to removal micropollutants from water [17-19]. Adsorption potential of selected activated carbons were tested and found that BPA was effectively removed from aqueous solution [20-23].

The aim of the study was: (1) determination of structural properties of studied activated carbons, (2) comparison of the effectiveness of removal of BPA using selected activated carbons, (3) fitting two kinetic models to analyze the experimental data, (4) determination of adsorption behaviour of BPA, (5) determination of impact of solution $\mathrm{pH}$ on sorption.

\section{Materials and methods}

\section{Characterization of the activated carbons}

Two kinds of commercial powder activated carbons were tested. Carbon AKPA-22 (Gryfskand, Poland) and SX2 (Norit (R), USA) were used for the comparative adsorption experiments. Both of them are being used for water conditioning. The sorbents used in this study did not subject any extra treatment in order to replicate their application in commercial water treatment processes. The sorbents were characterized by $\mathrm{N}_{2} / 77 \mathrm{~K}$ adsorption-desorption isotherms using ASAP 2010 analyzer (Micrometrics, USA).

\section{Adsorption experiments}

In order to determine kinetics and isotherms, batch experiments in an orbital shaker at $180 \mathrm{r} / \mathrm{min}$ were conducted. In the adsorption kinetics experiments, the concentration of activated carbon was equalled at $30 \mathrm{mg} / \mathrm{dm}^{3}$ and the initial concentration of BPA was at the 
level of $5 \mathrm{mg} / \mathrm{dm}^{3}$. At predetermined time intervals, the samples were filtered in order to separate sorbents from solution of BPA.

Isotherms studies can be investigated by varying the initial concentration of adsorbate or the sorbent amount. In this study, the sorbent concentrations were changing in the range from 10 to $120 \mathrm{mg} / \mathrm{dm}^{3}$ and the initial concentration of BPA was equalled at $15 \mathrm{mg} / \mathrm{dm}^{3}$. The experiments were conducted under ambient conditions. The flasks were put in a shaker for $3 \mathrm{~h}$. After finishing experiments, sorbents were separated from BPA solution. The concentration of BPA was determined using phenol cell test (photometric method, MERCK). The amount of BPA absorbed onto activated carbons was calculated according to the following equation:

$$
q_{e}=\frac{\left(C_{0}-C_{e}\right) \cdot v}{m}
$$

where $q_{e}[\mathrm{mg} / \mathrm{g}]$ is equilibrium adsorption amount, $C_{0}$ and $C_{e}\left[\mathrm{mg} / \mathrm{dm}^{3}\right]$ are the initial and equilibrium concentration of BPA, $v\left[\mathrm{dm}^{3}\right]$ is the volume of solution, $m[\mathrm{~g}]$ is the mass of sorbent.

\section{Results and discussion}

\section{Properties of activated carbon}

The nitrogen adsorption mensuration was used to determine isotherms type (Fig. 1) and calculate several parameters such as: the specific surface area, total area in pores, total pore volume (Table 1) and pore size distribution (PSD) (Fig. 2). According to the IUPAC (International Union of Pure and Applied Chemistry) categorization there are enumerated five isotherm types, each of them is characteristic for special sorbent and sorption mechanism. Carbon AKPA-22 indicated type I isotherm what proved presence of micropores. The lack of significant increase of adsorption at higher values of relative pressure followed from occurrence of very narrow pores, that it could not include more adsorbate than single monolayer. Type $I$ isotherm is characterized for chemisorption although several cases of physicosorption such as, for very microporus activated carbon could also belong to type I isotherm. In case of carbon SX2, long linear segment corresponds to multilayer physical adsorption and II type of isotherm. The specific surface area of carbons was determined by the standard BET method. The PSD of carbons was calculated according to method of Density Functional Theory (DFT), which is based on a molecular model for adsorption of nitrogen in porous solids. Both activated carbons have bidispersion porous structure, in majority consists of micropores and average fraction of mesopores, macropores do not occur.

Structural property of AKPA-22 and SX2

\begin{tabular}{|c|c|c|c|}
\hline Structure parameter & $\begin{array}{c}\text { BET surface area } \\
{\left[\mathbf{m}^{\mathbf{2}} / \mathbf{g}\right]}\end{array}$ & $\begin{array}{c}\text { Total area } \\
\text { in pores } \\
{\left[\mathbf{m}^{\mathbf{2}} / \mathbf{g}\right]}\end{array}$ & $\begin{array}{c}\text { Total pore } \\
\text { volume }\left[\mathbf{c m}^{\mathbf{3}} / \mathbf{g}\right]\end{array}$ \\
\hline AKPA-22 & 900.4 & 693.7 & 0.3652 \\
\hline SX2 & 821.8 & 689.9 & 0.4932 \\
\hline
\end{tabular}




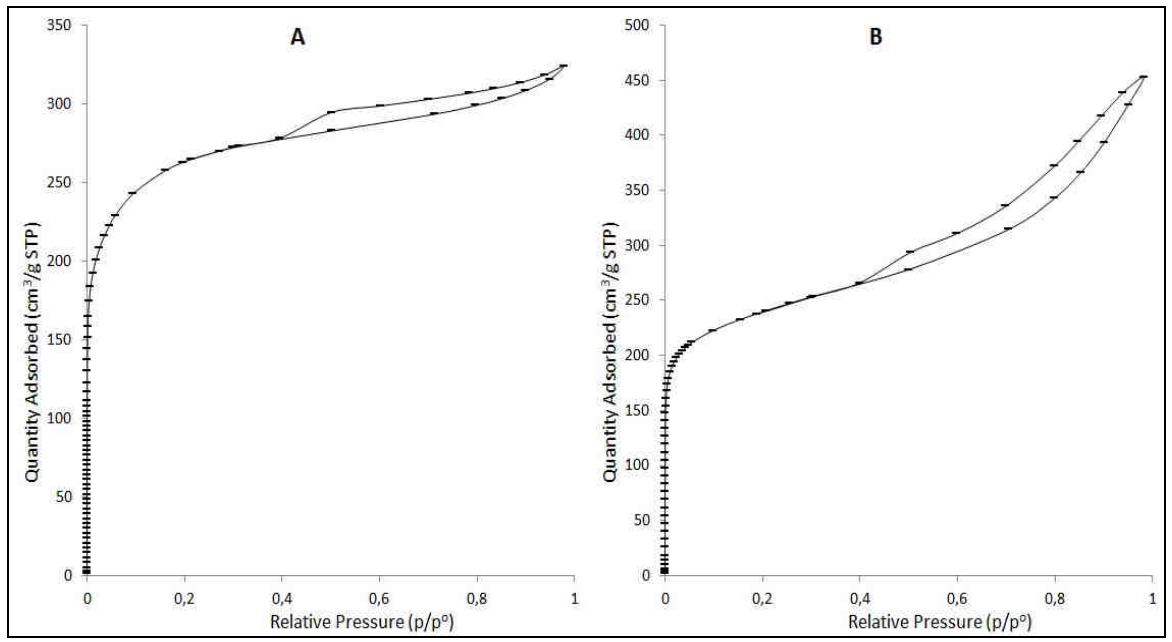

Fig. 1. Nitrogen adsorption-desorption isotherms of AKPA-22 (A) and SX2 (B)

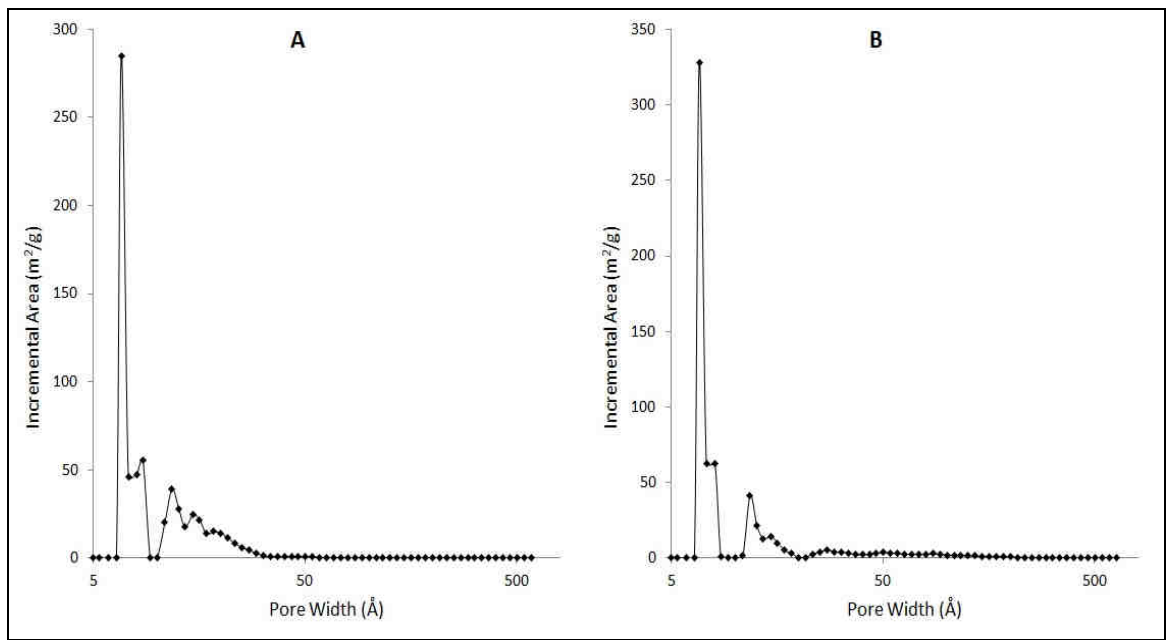

Fig. 2. Pore size distributions of AKPA-22 (A) and SX2 (B)

\section{Removal efficiency of BPA}

In this part the efficiency of BPA removal for AKPA-22 and SX2 was compared. The results of this comparative study were illustrated on Figure 3. The removal efficiency of BPA was in the range 9.6-85.7\% and $12.6-82.7 \%$ at the dosage change from $10 \mathrm{mg} / \mathrm{dm}^{3}$ to $110 \mathrm{mg} / \mathrm{dm}^{3}$ for AKPA-22 and SX2, respectively. In lower dosages of sorbents using SX2 showed little higher level of removal of BPA than AKPA-22. However in high dosages of sorbents reverse tendency was observed, higher removal of BPA was observed on AKPA-22 than on SX2. This study shows that both sorbents have ideal performance for removal bisphenol A from aqueous solutions. 


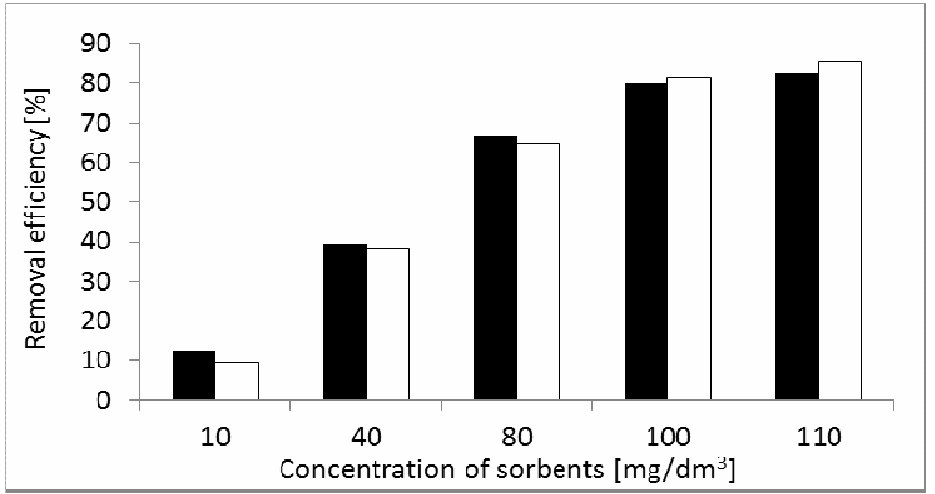

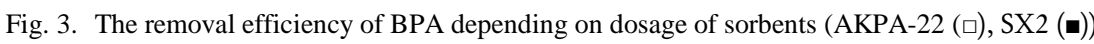

\section{Adsorption kinetics of BPA}

In order to determine the adsorption kinetics of BPA, the experimental data were analyzed using pseudo-first-order and pseudo-second-order kinetic models, which were given in the equations (2) and (3) respectively:

$$
\begin{gathered}
\ln \frac{\left(q_{e}-q_{t}\right)}{q_{e}}=-K_{1} \cdot t \\
\frac{t}{q_{t}}=\frac{1}{K_{2} \cdot q_{e 2}^{2}}+\frac{t}{q_{e}}
\end{gathered}
$$

where $q_{e}$ and $q_{t}$ are the amount of BPA adsorbed at equilibrium and at time $(t), K_{1}$ and $K_{2}$ are the pseudo-first-order and pseudo-second-order constants, respectively. Furthermore on the basis pseudo-second-order model were calculated the half adsorption time $\left(t_{1 / 2}\right)$ and the initial adsorption rate $(h)$ according to follows equations:

$$
\begin{gathered}
t_{1 / 2}=\frac{1}{k_{2} \cdot q_{e}} \\
h=k_{2} \cdot q_{e}^{2}
\end{gathered}
$$

Figure 4 shows adsorption of bisphenol A onto selected activated carbons versus time. Both curves resemble the same trend, however the equilibrium time of BPA onto AKPA-22 was shorter than onto SX2 and were equalled $180 \mathrm{~min}$ and $270 \mathrm{~min}$, respectively. This means that addition of BPA onto surface of AKPA-22 was faster than SX2. Figure 5 presents the results of fitting experimental data with kinetic models. The adsorption kinetic parameters listed in Table 2 show that the pseudo-second-order model fitted better the experimental data than pseudo-first-order model both for AKPA-22 and SX2. The adsorption capacity calculated from pseudo-second-order model $\left(q_{e(c a l)}\right)$ also corresponds well with the experimental data $\left(q_{\text {e(exp })}\right)$. The higher rate constant- $(h)$ and lower time required for half of $q_{e}-\left(t_{1 / 2}\right)$ of BPA to be absorbed of AKPA-22 confirm better adsorption of BPA than SX2. 


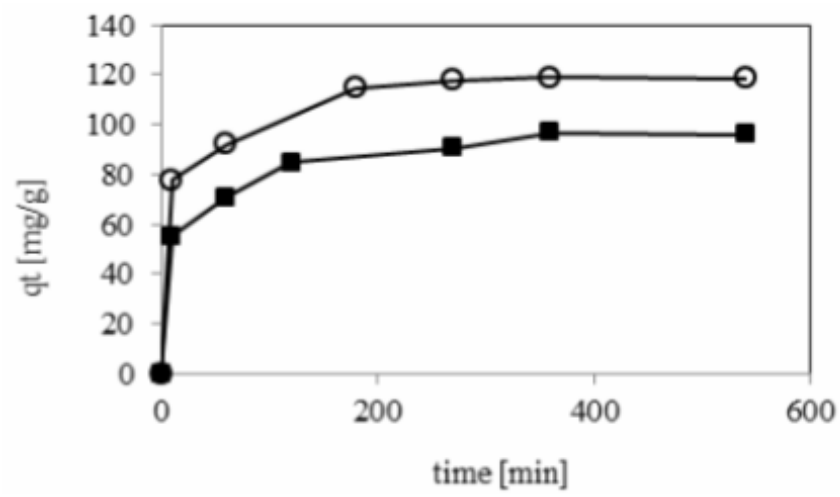

Fig. 4. Time-resolved uptake of BPA onto AKPA-22 (०) and SX2 (•)
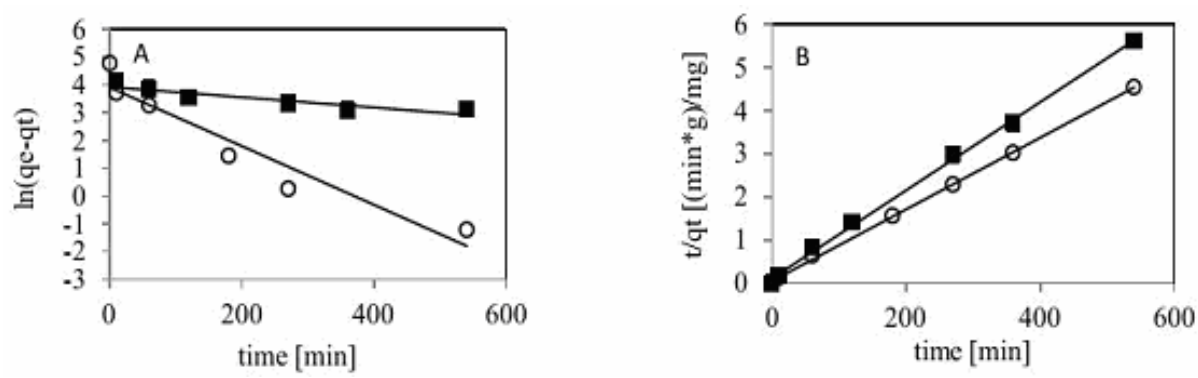

Fig. 5. Simulation of BPA adsorption onto AKPA-22 (०) and SX2 (•) by means of pseudo-first-order kinetics (A) and pseudo-second-order kinetics (B)

Adsorption constants rate for two kinetic models

\begin{tabular}{|c|c|c|c|c|c|c|c|c|}
\hline \multirow{2}{*}{ Adsorbent } & \multicolumn{2}{|c|}{$\begin{array}{c}\text { Pseudo-first-order } \\
\text { equation }\end{array}$} & \multicolumn{6}{|c|}{ Pseudo-second-order equation } \\
\cline { 2 - 9 } & $\boldsymbol{K}_{\mathbf{1}}[\mathbf{1} / \mathbf{m i n}]$ & $\mathbf{R}^{\mathbf{2}}$ & $\begin{array}{c}\boldsymbol{K}_{\mathbf{2}} \\
{[\mathbf{g} /(\mathbf{m g} \cdot \mathbf{m i n})]}\end{array}$ & $\boldsymbol{q}_{\boldsymbol{e} 2(\text { exp })}[\mathbf{m g} / \mathbf{g}]$ & $\boldsymbol{q}_{\boldsymbol{e} 2(\text { cal })}[\mathbf{m g} / \mathbf{g}]$ & $\begin{array}{c}\boldsymbol{t}_{\mathbf{1} / \mathbf{2}} \\
{[\mathbf{m i n}]}\end{array}$ & $\begin{array}{c}\boldsymbol{h} \\
[\mathbf{m g} / \mathbf{( g} \cdot \mathbf{m i n})]\end{array}$ & $\mathbf{R}^{\mathbf{2}}$ \\
\hline AKPA-22 & 0.0106 & 0.921 & 0.001 & 118.7 & 120.48 & 8.3 & 14.51 & 0.9992 \\
\hline SX2 & 0.0019 & 0.8049 & 0.00085 & 97 & 98.03 & 12 & 8.16 & 0.9981 \\
\hline
\end{tabular}

\section{Adsorption isotherms of BPA}

The isothermal data were fitted to Freundlich and Langmuir models according to the linear equation. The equations are as follows:

- The Freundlich equation:

$$
\log q_{e}=\log K_{F}+\frac{1}{n} \log C_{e}
$$

where $K_{F}\left[\mathrm{mg}\left(\mathrm{dm}^{3} / \mathrm{mg}\right)^{1 / 2} / \mathrm{g}\right]$ is the Freundlich constant reflects the bonding energy, the parameter $1 / n$ with value between $0-1$ describes adsorption intensity or surface heterogeneity. $q_{e}[\mathrm{mg} / \mathrm{g}]$ and $C_{e}\left[\mathrm{mg} / \mathrm{dm}^{3}\right]$ are the uptake capacity and the equilibrium concentration respectively. 
- The Langmuir equation:

$$
\frac{1}{q_{e}}=\frac{1}{q_{m} \cdot K_{L}} \cdot \frac{1}{C_{e}}+\frac{1}{q_{m}}
$$

where $q_{e}[\mathrm{mg} / \mathrm{g}]$ and $C_{e}\left[\mathrm{mg} / \mathrm{dm}^{3}\right]$ are the uptake capacity and the equilibrium concentration respectively. $K_{L}\left[\mathrm{dm}^{3} / \mathrm{mg}\right]$ is the Langmuir constant and $q_{m}[\mathrm{mg} / \mathrm{g}]$ is the maximum adsorption capacity.

The parameters of models are summarized in Table 3 only for AKPA-22 because in case of SX2 bad fitting was obtained. This indicated that Langmuir and Freundlich models are not sufficient to describe adsorption of BPA onto SX2 and another mixed models were needed for this isotherms. Compared with Langmuir model, Freundlich model fitted the experimental data better because the $\mathrm{R}^{2}$ values were higher for Freundlich than Langmuir models for sorbent AKPA-22. The Langmuir theory assumes monolayer adsorption where molecules interact only with the surface of sorbent. On the other hand Freundlich theory describes multilayer coverage where molecules interact with the surface of sorbent and then with each other. The high value of $\mathrm{R}^{2}$ demonstrates that BPA forms multimolecular layer on the surface of AKPA-22. The $1 / \mathrm{n}$ value was less than 1 indicating a favorable adsorption system and heterogenity of the sorbent adsorption sites.

Table 3

Fitted parameters using Freundlich and Langmuir models for adsorption of BPA by AKPA-22 and SX2

\begin{tabular}{|c|c|c|c|c|}
\hline \multirow{2}{*}{ Adsorbent } & \multicolumn{2}{|c|}{ Freundlich model } & \multicolumn{2}{c|}{ Langmuir model } \\
\cline { 2 - 5 } & $K_{\boldsymbol{F}}\left[\mathbf{m g}\left(\mathbf{d m}^{\mathbf{3}} / \mathbf{m g}\right)^{\mathbf{1 / 2}} / \mathbf{g}\right]$ & $\mathbf{1} / \boldsymbol{n}$ & $K_{L}\left[\mathbf{d m}^{\mathbf{3}} / \mathbf{m g}\right]$ & $\boldsymbol{q}_{\boldsymbol{m}}[\mathbf{m g} / \mathbf{g}]$ \\
\hline AKPA-22 & 97.49 & 0.12 & 2.37 & 131.57 \\
\hline
\end{tabular}

\section{Effect of solution pH}

The impact of solution $\mathrm{pH}$ on the adsorption of BPA was evaluated at the $\mathrm{pH}$ range from 3 to 12 at activated carbons (AKPA-22, SX2) dosage of $70 \mathrm{mg} / \mathrm{dm}^{3}$ and initial concentration of BPA of $15 \mathrm{mg} / \mathrm{dm}^{3}$. The $\mathrm{pH}$ of medium was adjusted using $\mathrm{NaOH}$ and $\mathrm{HCl}$ solutions. The equilibrium concentration as function of $\mathrm{pH}$ is shown in Figure 6. Adjusting the $\mathrm{pH}$ of solution from 3 to 10 did not influence the adsorption of BPA. However decrease of BPA adsorption was observed for both activated carbon when solution $\mathrm{pH}$ exceeded 10 . It is well known that BPA is weak acid with $\mathrm{pK}_{\mathrm{a}}$ value between 9.6-10.2. Therefore in alkaline medium BPA molecules gave up a proton and formed bisphenolate anions. Decrease of adsorption when $\mathrm{pH}>\mathrm{pKa}$ was obvious because of enhancing repulsion forces and reduction $\pi-\pi$ interaction between bisphenolate anions and surface of activated carbon.

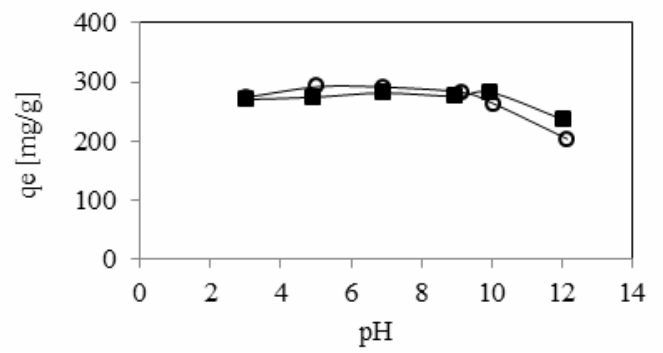

Fig. 6. Equilibrium adsorption of BPA on AKPA-22 (०) and SX2 (•) at different pH values 


\section{Conclusions}

- Characterization of AKPA-22 and SX2 by nitrogen adsorption-desorption isotherms proves bidispersion structure with the largest amount of micropores and average fraction of mesopores, macropores do not occur. The BET surface area equals 900.4 and $821.8 \mathrm{~m}^{2} / \mathrm{g}$ for AKPA-22 and SX2, respectively.

- The study indicated high removal efficiencies of BPA using both sorbents (AKPA-22, $\mathrm{SX} 2$ ), which proves that sorption on activated carbon is low-cost method.

- The kinetics data fitted better with the pseudo-second-order model than pseudo-first-order model fitted.

- Adsorption of BPA on AKPA-22 was faster than on SX2.

- Adsorption isotherms fitted better with the Freundlich model than the Langmuir model.

- Increase of solution $\mathrm{pH}$ above 10 had significant impact on adsorption BPA. When $\mathrm{pH}>p K_{a}$ charge of adsorbate and amphoteric adsorbent was negative that lead to increase repulsion forces and reduction of $\pi-\pi$ interaction.

\section{References}

[1] Kurata Y, Ono Y, Ono Y. Occurrence of phenols in leachates from municipal solid waste landfill sites in Japan. J Mater Cycles and Waste Manage. 2008;2:144-152. DOI: 10.1007/s10163-008-0200-X.

[2] Lee H, Peart T, Gris G, Chan J. Endocrine-disrupting chemicals in industrial wastewater samples in Toronto, Ontario. Water Qual Res J Canada. 2002;37:459-472.

[3] Mohapatra DP, Brar SK, Tyagi RD, Surampalli RY. Physico-chemical pretreatment and biotransformation of wastewater and wastewater sludge-fate of bisphenol A. Chemosphere. 2010;78:923-94. DOI: 10.1016/j.chemosphere.2009.12.053.

[4] Gibson R, Becerril-Bravo E, Silva-Castro V, Jimenez B. Determination of acidic pharmaceuticals and potential endocrine disrupting compounds in wastewater and spring waters by selective elution and analysis by gas chromatography-mass spectrometry. J Chromatography. 2007;1169:31-39. DOI: 10.1016/j.chroma.2007.08.056.

[5] Yamamoto T, Yasuhara A, Shiraishi H, Nakasugi O. Bisphenol A in hazardous waste landfill leachates. Chemosphere. 2001;42:415-418. DOI: 10.1016/S0045-6535(00)00079-5.

[6] Urase T, Miyashita K. Factors affecting the concentrations of Bisphenol A in leachates from solid waste disposal and its fate in treatment processes. J Mater Cycles and Waste Manage. 2003;5:77-82.

[7] Liu R, Chen G, Tam N, Luan T, Shin P, Cheung S, Liu Y. Toxicity of bisphenol A and its bioaccumulation and removal by a marine microalga Stephanodiscus hantzschii. Ecotoxicol and Environ Safety. 2009;72:321-32. DOI: 10.1016/j.ecoenv.2008.05.012.

[8] Newbold R, Jefferson W, Padilla-Banks E. Prenatal exposure to bisphenol A at environmentally relevant doses adversely affects the murine female reproductive tract later in life. Environ Health Perspect. 2009;117:879-885. DOI: 10.1289/ehp.0800045.

[9] Mihaich E, Friderich U, Caspers N, Hall T, Klecka G, Dimond S, Staples C, Ortego L, Hentges S. Acute and chronic toxicity testing of bisphenol A with aquatic invertebrates and plants. Ecotoxicol and Environ Safety. 2009;72:1392-1399. DOI: 10.1016/j.ecoenv.2009.02.005.

[10] Crain D, Eriksen M, Iguchi T, Jobling S, Laufer H, LeBlanc G, Jr L. An ecological assessment of bisphenol-A: Evidence from comparative biology. Reproduct Toxicol. 2007;24:225-239. DOI: 10.1016/j.reprotox.2007.05.008.

[11] Bodzek M, Dudziak M. Elimination of steroidal sex hormones by conventional water treatment and membrane process. Desalination. 2006;198:198:24-32. DOI: 10.1016/j.desal.2006.09.005.

[12] Dudziak M, Bodzek M. Usuwanie mikrozanieczyszczeń estrogenicznych z roztworów wodnych w wysoko ciśnieniowych procesach membranowych. Ochr Środow. 2009;3:33-36.

[13] Braeken L, Van der Bruggen B. Feasibility of nanofiltration for the removal of endocrine disrupting compounds. Desalination. 2009;240:127-131. DOI: 10.1016/j.desal.2007.11.069.

[14] Zhang Y, Causserand C, Aimar P, Cravedi J. Removal of bisphenol A by a nanofiltration membrane in view of drinking water production. Water Res. 2006;40:3793-3799. DOI: 10.1016/j.watres.2006.09.011. 
[15] Liu W, Zhang H, Cao B, Lin K, Gan J. Oxidative removal of bisphenol A using zero valent aluminum-acid system. Water Res. 2011;45:1872-1878. DOI: 10.1016/j.wat res.2010.12.00.

[16] Meier J, Melin T, Eilers L. Nanofiltration and adsorption on powdered adsorbent as process combination for the treatment of severely contaminated wastewater. Desalination. 2002;146:361-366. DOI: 10.1016/S00119164(02)00513-1.

[17] Fukuhara T, Iwasaki S, Kawashima M, Shinohara O, Abe I. Adsorbability of estrone and 17ß-estradiol in water onto activated carbon. Water Res. 2006;40:241-248. DOI: 10.1016/j.watres.2005.10.042.

[18] Moreno-Castilla C. Adsorption of organic molecules from aqueous solutions on carbon materials. Carbon. 2004;42:83-94. DOI: 10.1016/j.carbon.2003.09.022.

[19] Sui Q, Huang Y, Liu Y, Chang X, Ji G, Deng S, Xie T, Yu G. Rapid removal of bisphenol A on highly ordered mesoporous carbon. J Environ Sci. 2011;23:177-182. DOI: 10.1016/S1001-0742(10)60391-9.

[20] Bautista-Toledo I, Ferro-Garcia M.A, Rivera-Utrilla J, Moreno-Castilla C, Vegas Fernandez FJ. Bisphenol A removal from water by activated carbon. Effect of carbon characteristics and solution chemistry. Environ Sci Technol. 2005;39:6246-6250. DOI:10.1021/es0481169.

[21] Liu G, Ma J, Qin Q. Adsorption of bisphenol A from aqueous solution onto activated carbons with different modification treatments. J Hazards Mater. 2009;164:1275-1280. DOI: 10.1016/j.jhazmat.2008.09.038.

[22] Tsai W, Lai C, Su T. Adsorption of bisphenol-A from aqueous solution onto minerals and carbon adsorbents. J Hazard Mater. 2006;134:169-175. DOI: 10.1016/j.jhazmat.2005.10.055.

[23] Yamanaka Y, Moriyoshi K, Ohmoto T, Ohe T, Sakai K. Efficient microbial degradation of bisphenol A in the presence of activated carbon. J of Biosci and Bioengin. 2008;105:157-160, DOI: 10.12 63/jbb.105.157.

\title{
SKUTECZNOŚĆ USUWANIA BISFENOLU A NA KRAJOWYCH I ZAGRANICZNYCH WEGLACH AKTYWNYCH
}

\author{
${ }^{1}$ Instytut Inżynierii Wody i Ścieków, Politechnika Śląska
}

\begin{abstract}
Abstrakt: Masowe wykorzystywanie bisfenolu A (BPA) do produkcji tworzyw sztucznych i opakowań na żywność powoduje wzrost stężenia tego związku w środowisku. Zarówno wody powierzchniowe, podziemne, jak i morskie ulegają coraz większemu skażeniu bisfenolem A. Niepokojący jest fakt, że BPA obecny w ściekach w znacznym stopniu ulega sorpcji na kłaczkach osadu czynnego, co wskazuje na dodatkowe źródło zanieczyszczenia środowiska tym związkiem. Zasorbowany na osadzie bisfenol A trwale pozostaje w środowisku, wywołując niekorzystne efekty biologiczne głównie o charakterze hormonalnym. Zagrożenie, jakie stanowi ten związek, powoduje konieczność poszukiwania efektywnych metod jego usuwania. W pracy określono możliwość usuwania BPA z roztworów wodnych na krajowych i zagranicznych węglach aktywnych. Na podstawie danych doświadczalnych wyznaczono kinetykę i typ procesu sorpcji.
\end{abstract}

Słowa kluczowe: mikrozanieczyszczenia, sorpcja, węgle aktywne 